\title{
Typing of human rotaviruses: Nucleotide mismatches between the VP7 gene and primer are associated with genotyping failure
} Mustafizur Rahman*1,2, Rasheda Sultana ${ }^{1}$, Goutam Podder ${ }^{1}$, Abu SG Faruque ${ }^{1}$, Jelle Matthijnssens ${ }^{2}$, Khalequz Zaman ${ }^{1}$, Robert F Breiman ${ }^{1}$, David A Sack ${ }^{1}$, Marc Van Ranst ${ }^{2}$ and Tasnim Azim ${ }^{1}$

Address: ${ }^{1}$ ICDDR,B: Centre for Health and Population Research, Mohakhali, Dhaka-1212, Bangladesh and ${ }^{2}$ Laboratory of Clinical and Epidemiological Virology, Rega Institute for Medical Research, University of Leuven, B-3000, Leuven, Belgium

Email: Mustafizur Rahman* - mustafizur.rahman@uz.kuleuven.ac.be; Rasheda Sultana - rasheda_sultana@yahoo.com; Goutam Podder - gpodder@icddrb.org; Abu SG Faruque - faruque@icddrb.org; Jelle Matthijnssens - jelle.matthijnssens@uz.kuleuven.ac.be; Khalequz Zaman - kzaman@icddrb.org; Robert F Breiman - rbreiman@cdcnairobi.mimcom.net; David A Sack - dsack@icddrb.org; Marc Van Ranst - marc.vanranst@uz.kuleuven.ac.be; Tasnim Azim - tasnim@icddrb.org

* Corresponding author

Published: 24 March 2005

Virology Journal 2005, 2:24 doi:10.1186/1743-422X-2-24

This article is available from: http://www.virologyj.com/content/2/I/24

(C) 2005 Rahman et al; licensee BioMed Central Ltd.

This is an Open Access article distributed under the terms of the Creative Commons Attribution License (http://creativecommons.org/licenses/by/2.0), which permits unrestricted use, distribution, and reproduction in any medium, provided the original work is properly cited.
Received: 06 March 2005

Accepted: 24 March 2005

\begin{abstract}
Background: Rotavirus genotyping is performed by using reverse transcription PCR with typespecific-primers. Because the high rotavirus mutation rate generates an extensive genomic variation, different G-type-specific primer sets are applied in different geographical locations. In Bangladesh, a significant proportion (36.9\%) of the rotavirus strains isolated in 2002 could not be G-typed using the routinely used primer set. To investigate the reason why the strains were untypeable, nucleotide sequencing of the VP7 genes was performed.
\end{abstract}

Results: Four nucleotide substitutions at the GI primer-binding site of the VP7 gene of Bangladeshi GI rotaviruses rendered a major proportion of circulating strains untypeable using the routine primer set. Using an alternative primer set, we could identify GI rotaviruses as the most prevalent genotype (44.8\%), followed by G9 (2I.7\%), G2 (I5.0\%) and G4 (I3.8\%).

Conclusion: Because of the natural variation in the rotaviral gene sequences, close monitoring of rotavirus genotyping methods is important.

\section{Background}

Rotaviruses remain the most common cause of acute gastroenteritis worldwide and cause an estimated 600,000 deaths in children less than 5 years of age [20]. The high disease burden motivated major efforts to develop a suitable rotavirus vaccine. However, the vaccine efficacy is being challenged by the extensive strain diversity of the rotaviruses $[3,7-9,13,14]$.
Rotaviruses belong to the Reoviridae, and their genome consists of 11 segments of double stranded RNA. The gene segment coding for the VP7 glycoprotein is the basis for genotyping group A rotaviruses into at least 15 G-genotypes. Among them, G1, G2, G3, G4 and G9 are the most common G-types in humans $[5,15,16,19,21,23]$. The importance of type-specific immunological protection against rotavirus disease is still under discussion [13]. 
G-genotyping is performed using type-specific-primerbased RT-PCR. Two common primer sets introduced by Gouvea et al. [6] and Das et al. [2] are currently used in rotavirus G-typing surveillance programs [22]. A failure to genotype or mistyping has already been reported from different parts of the world. These reports showed that nucleotide sequence differences between the target region of the respective genes and the primer sequences used for typing led to the genotyping failure $[1,10,11,17]$.

The Dhaka hospital of ICDDR,B, situated in the central Bangladesh, and the Matlab hospital, located $45 \mathrm{~km}$ south east of Dhaka respectively treat about 100,000 and 15,000 diarrhoeal patients each year. A hospital surveillance system has been established in these hospitals by ICDDR,B to collect information on clinical, epidemiological and demographic characteristics of the patients attending the hospital since 1978. In Bangladesh, rotavirus strains have previously been typed using a variety of techniques. Serotyping was introduced by Ward et al. [28] with specimens collected during 1985-1986 in Dhaka using neutralization with hyperimmune antisera against prototype rotavirus strains G1, G2, G3 and G4. They concluded that epitopic variations between rotavirus strains influenced the sensitivity of serotyping. Fun et al. [4] detected the major rotavirus types (G1 to G4) by RNA hybridization with serotype-specific synthetic oligonucleotide probes, but this method could not type $33.3 \%$ of the Bangladeshi rotaviruses. Likewise, RT-PCR depending on type-specific oligonucleotide primers failed to type a significant portion of rotaviruses. Rotavirus surveillance studies in Bangladesh between 1987 and 1997 reported that 1,095 (43.7\%) samples out of 2,515 were G-untypeable [25-27].

In this study, we characterized rotavirus positive stool specimens collected in the Dhaka and Matlab hospitals during 2002 by using RT-PCR based on the primer set described by Das et al. [2]. We found that a major proportion of the specimens were untypeable. Nucleotide sequences of VP7 genes were performed to investigate the reason why they were untypeable with the routine primer set. The untypeable specimens were further characterized by using a different primer set described by Gouvea et al. [6].

\section{Results and Discussion} Detection of rotavirus strains

In 2002, a total of 3,803 patients with history of watery diarrhea were included in the hospital surveillance system. In Dhaka and Matlab, 535 (27.2\%) and 358 (19.4\%) specimens were positive for group A rotavirus antigens by enzyme immunoassay.

\section{G typing using the Das primer set}

Rotavirus G-typing was carried out for all rotavirus positive specimens from Matlab and for every fourth of the rotavirus-positive specimens from Dhaka. Some samples were excluded from this study due to unavailability of sufficient amount of stool specimens for testing. G-typing was performed on 433 rotavirus ELISA-positive stool samples by RT-PCR using the primer set described by Das et al. [4], which was routinely used in our laboratory. The most prevalent G types were G9 (20.5\%); G2 (14.6\%), and G4 $(13.8 \%)$. G1 comprised only $11.6 \%$ of the isolates and $36.9 \%$ of the rotavirus-positive samples were untypeable.

\section{VP7 gene sequence analysis}

We amplified the VP7 genes of five randomly selected untypeable strains (Dhaka162-02, Dhaka18-02, Dhaka164-02 Dhaka165-02 and Matlab26-02) using the VP7 consensus primers Beg9-End9 as described by Gouva et al. [6] and sequenced their complete open reading frame [GenBank:AY631050, GenBank:AY631054]. They were typed as G1 rotaviruses by using BLAST homology searches (99-100\% nucleotide and amino acid identities with the Indian G1 rotavirus strain, ISO-4). To compare them with the typeable G1 sequences, the VP7 genes of two typeable G1 strains, Dhaka8-02 [GenBank:AY631049] and Matlab159-02 [GenBank:AY631055] were sequenced. We found that the nucleotide sequences of the typeable and untypeable G1 strains were $100 \%$ identical at the G1 primer-binding sites. We aligned the target G1 VP7 sequence with the Das G1 primer sequence (reverse primer, 9T1-1; 5'-TCTTGTCAAAGCAAATAATG-3'; nt 176-195, prototype strain Wa [GenBank:M21843]) to determine if there was any mismatch between them. Four mismatches were found in the Das G1 primer, 9T1-1, at the 5' end (Fig. 2). Due to these mismatches, the Das G1 primer failed to detect most $(75 \%)$ of the G1 strains. Since, the primer set had perfect matches at the 3 ' end, it could detect $25 \%$ of the G1 rotaviruses. When we compared the target sequence with the Gouvea G1 primer sequence (forward primer, aBT1; 5'CAAGTACTCAAATCAATGATGG-3'; nt 314-335, prototype strain Wa), we found only one mismatch (Fig. 2). Therefore, the Gouvea G1 primer was found to be more suitable for typing our G1 strains.

\section{Distribution of $\mathbf{G}$ types using Gouvea primer set}

The untypeable specimens were typed using the primer set described by Gouvea et al. [6]. After typing with the Gouvea primer set, the distribution of rotavirus G-types changed dramatically (Fig. 1). Type G1 now accounted for $44.8 \%$ of the isolates and became the most prevalent genotype, and the number of untypeable strains was reduced from 36.9 to $2.1 \%$. The other common G types were G9 $(21.7 \%)$, G2 $(15.0 \%)$, and G4 (13.8\%). The previous studies in Bangladesh reported that G4 strains were the 

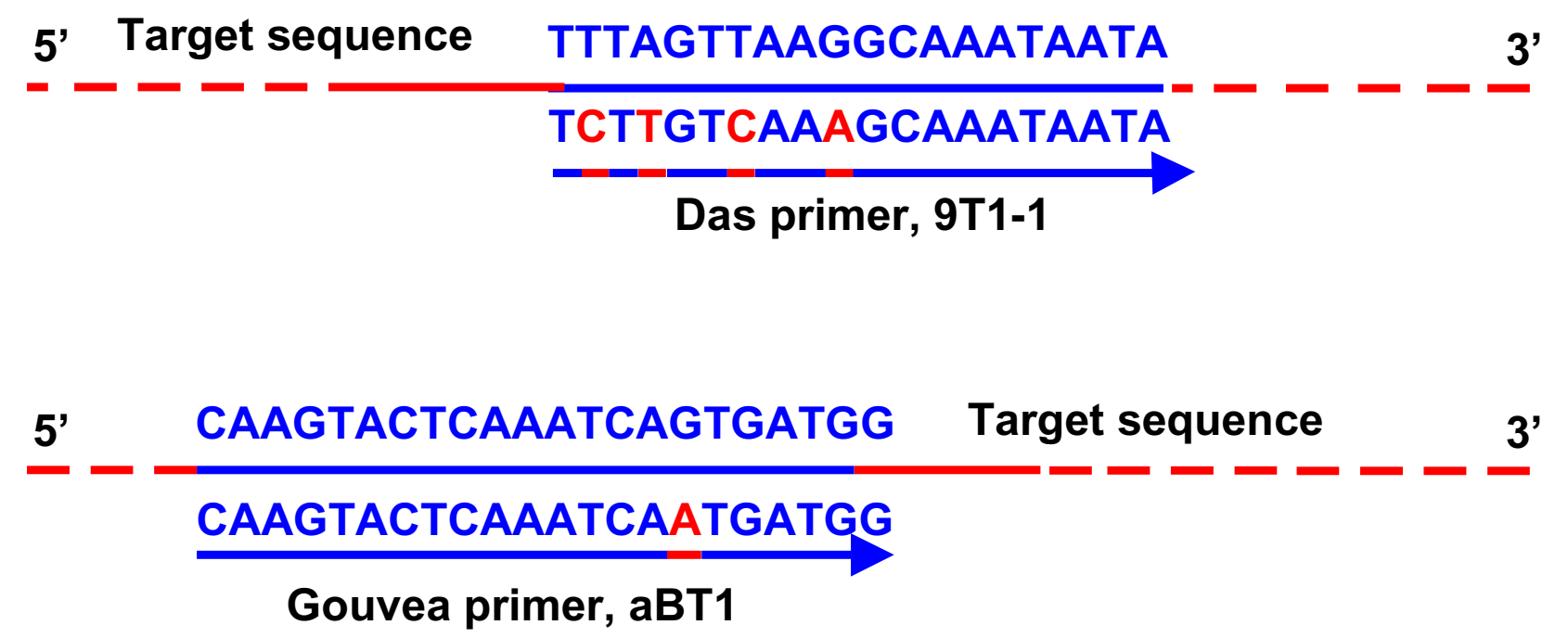

Figure 2

Nucleotide mismatches in the primers. The target sequence is the VP7 gene of GI Bangladeshi strains. The GI rotavirus VP7 gene specific primers were described by Das et al. [2] and Gouvea et al. [6]. Mismatches are in red.

most prevalent strains during 1992-1997 and a significant number of rotavirus strains were untypeable using the Das primer set [26]. It is likely that the Das primer set could not detect most of the G1 rotaviruses in the previous years and that a majority of the untypeable rotaviruses were G1 strains.

\section{Conclusion}

Because of the natural variation in the rotaviral gene sequences, close monitoring of rotavirus genotyping methods is important. The findings described in this paper will be important for genotyping strategies in the rotavirus surveillance studies.

\section{Materials and methods Sample collection}

Stool specimens were collected from patients who presented with diarrhea to the Dhaka and Matlab hospitals of ICDDR,B in 2002. In the Dhaka hospital, stool specimens are routinely collected from every $50^{\text {th }}$ patient and in Matlab hospital, every patient with diarrhea submits a stool specimen for testing.

\section{Rotavirus antigen detection}

Rotavirus antigens (group A-specific VP6 proteins) were detected in the stool specimen using a solid phase sandwich type enzyme immunoassay modelled after Dako- patts commercial kit incorporating rabbit hyperimmune antisera produced at ICDDR,B and an anti-human rotavirus-horseradish peroxidase conjugate (Dakopatts, Copenhagen, Denmark) using the same criteria for determination of positivity as those used by the Dakopatts kit [26].

\section{RNA extraction}

The QIAamp Viral RNA mini kit (Qiagen/Westburg, Leusden, The Netherlands) was used according to the manufacturer's instructions for the extraction of rotavirus RNA from the stool samples.

\section{RT-PCR}

A reverse transcriptase-polymerase chain reaction (RTPCR) was carried out using the Qiagen OneStep RT-PCR Kit (Qiagen/Westburg) as previously described by Das et al. [2] and Gouvea et al. [6] for rotavirus G-types (G1, G2, G3, G4 and G9) using type-specific oligonucleotide primers. The reaction was carried out with an initial reverse transcription step at $45^{\circ} \mathrm{C}$ for $30 \mathrm{~min}$, followed by 35 cycles of amplification ( $30 \mathrm{sec}$ at $94^{\circ} \mathrm{C}, 30 \mathrm{sec}$ at $50^{\circ} \mathrm{C}, 1$ min at $72^{\circ} \mathrm{C}$ ), and a final extension of $7 \mathrm{~min}$ at $72^{\circ} \mathrm{C}$ in a thermal cycler (Eppendorf, Hamburg, AG). PCR products were run on a $2 \%$ agarose gel, and stained with ethidium bromide. Specific segment sizes for the different $G$ types were visualized under UV-light. 


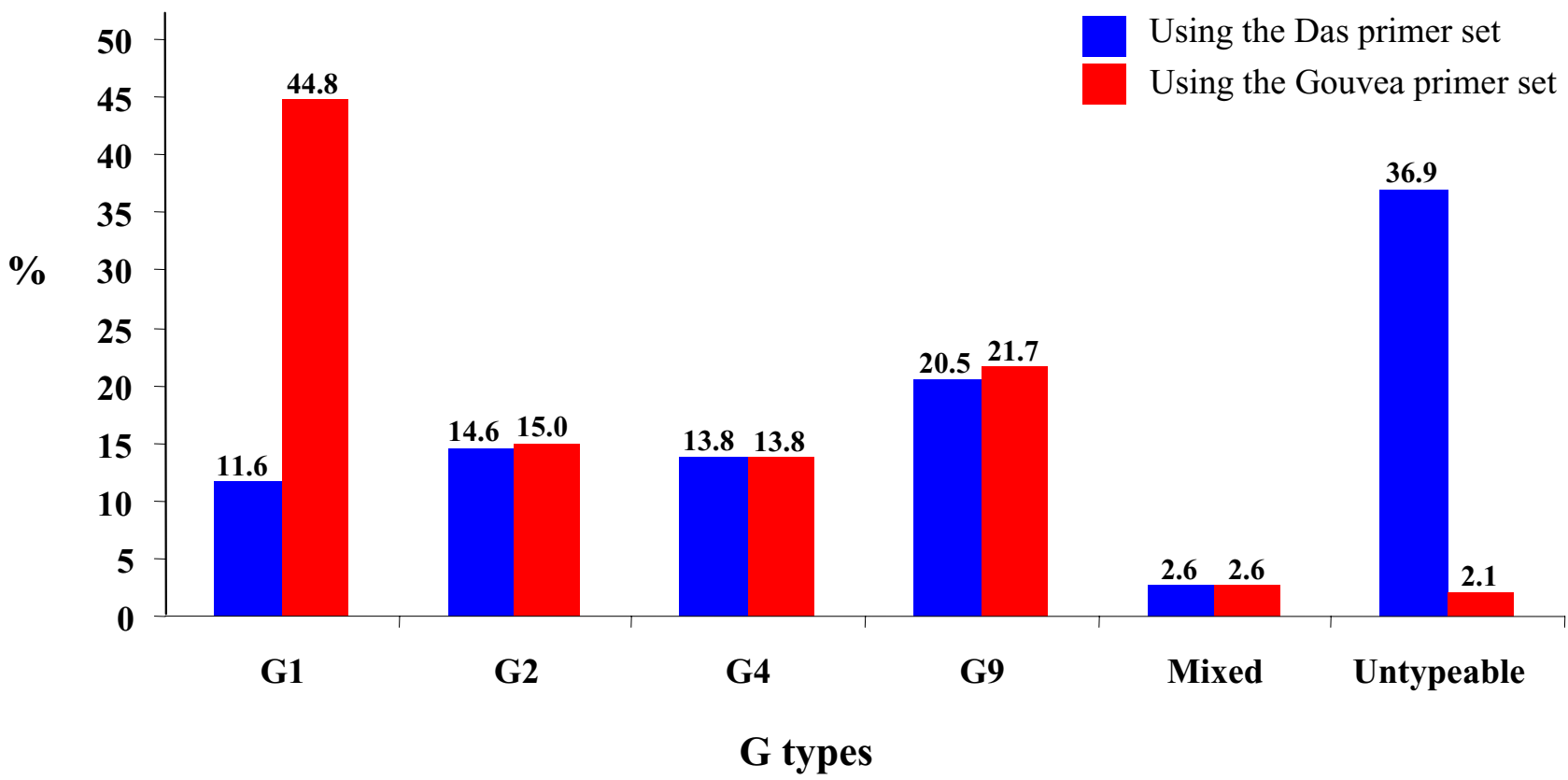

Figure I

Effect of untypeable strains on G typing of Bangladeshi rotavirus strains isolated in $2002(n=433)$.

\section{Nucleotide sequencing}

The amplified PCR products were purified with the QIA quick PCR purification kit (Qiagen/Westburg), and sequenced in both directions using the dideoxy-nucleotide chain termination method with the ABI PRISM ${ }^{\circledast}$ BigDye Terminator Cycle Sequencing Reaction kit (Perkin-Elmer Applied Biosystems, Foster City, California) on an automated sequencer (ABI PRISM ${ }^{\mathrm{TM}}$ 3100). The Beg9 and End9 RT-PCR primers were used as sequencing primers.

\section{Sequence analysis}

The chromatogram sequencing files were inspected using Chromas 2.2 (Technelysium, Queensland, Australia), and consensus sequences were prepared using SeqMan II (DNASTAR, Madison, WI). Multiple sequence alignments were performed using CLUSTALX 1.81 [24]. Sequences were manually edited in the GeneDoc version 2.6.002 alignment editor [18].

\section{Sequence submission}

The nucleotide sequence data were deposited in GenBank using the National Center for Biotechnology Information (NCBI, Bethesda, MD) Sequin 5.15 submission tool http:/ /www3.ncbi.nlm.nih.gov/ under accession numbers AY631049-AY631055.

\section{Competing interests}

The author(s) declare that they have no competing interests.

\section{Authors' contributions}

MR carried out the laboratory tests and wrote the manuscript; RS and GP carried out RT-PCR tests; JM performed the sequencing experiments; $\mathrm{AF}, \mathrm{KZ}, \mathrm{RB}$ and $\mathrm{DS}$ supervised the rotavirus surveillance program and critically revised the manuscript; MVR and TA supervised the study.

\section{Acknowledgements}

This study was funded by the Program for Appropriate Technology in Health (PATH), grant number GAT 770-790-0I45I-SPS. ICDDR,B acknowledges with gratitude the commitment of PATH to the Centre's research efforts.

\section{References}

I. Adah MI, Rohwedder A, Olaleyle OD, Werchau H: Nigerian rotavirus serotype $\mathbf{6 8}$ could not be typed by PCR due to nucleotide mutation at the $3^{\prime}$ end of the primer binding site. Arch Virol 1997, I42: |88|-1887. 
2. Das BK, Gentsch JR, Cicirello HG, Woods PA, Gupta A, Ramachandran M, Kumar R, Bhan MK, Glass RI: Characterization of rotavirus strains from newborns in New Delhi, India. J Clin Microbiol 1994, 32: 1820-1822.

3. Estes MK: Rotaviruses and their replication. In Fields virology Edited by: Howley PM. Philadelphia, Lippincott Williams \& Wilkins; 200I:1747-1786

4. Fun BN, Unicomb L, Rahim Z, Banu NN, Podder G, Clemens J, Van Loon FP, Rao MR, Malek A, Tzipori S: Rotavirus-associated diarrhea in rural Bangladesh: two-year study of incidence and serotype distribution. J Clin Microbiol I99I, 29:1359-I 363.

5. Gentsch JR, Woods PA, Ramachandran M, Das BK, Leite JP, Alfieri A, Kumar R, Bhan MK, Glass RI: Review of $\mathbf{G}$ and $\mathbf{P}$ typing results from a global collection of rotavirus strains: implications for vaccine development. J Infect Dis 1996, 174:S30-S36.

6. Gouvea V, Glass RI, Woods P, Taniguchi K, Clark HF, Forrester B Polymerase chain reaction amplification and typing of rotavirus nucleic acid from stool specimens. J Clin Microbiol 1990, 28:276-282.

7. Green KY, Sears JF, Taniguchi K, Midthun K, Hoshino Y, Gorziglia M, Nishikawa K, Urasawa S, Kapikian AZ, Chanock RM: Prediction of human rotavirus serotype by nucleotide sequence analysis of the VP7 protein gene. J Virol 1988, 62: I819-1823.

8. Green KY, Midthun K, Gorziglia M, Hoshino Y, Kapikian AZ, Chanock RM, Flores J: Comparison of the amino acid sequences of the major neutralization protein of four human rotavirus serotypes. Virology 1987, 161:153-159.

9. Hoshino Y, Nishikawa K, Benfield DA, Gorziglia M: Mapping of antigenic sites involved in serotype-cross-reactive neutralization on group A rotavirus outercapsid glycoprotein VP7. Virology 1994, 199:233-237.

10. Iturriza-Gomara M, Kang G, Mammen A, Jana AK, Abraham M, Desselberger U, Brown D, Gray J: Characterization of GIOP [I I] rotaviruses causing acute gastroenteritis in neonates and infants in Vellore, India. J Clin Microbiol 2004, 42:254I-2547.

II. Iturriza-Gomara M, Green J, Brown DW, Desselberger U, Gray J]: Diversity within the VP4 gene of rotavirus $P[8]$ strains: implications for reverse transcription-PCR genotyping. J Clin Microbiol 2000, 38:898-90I.

12. Jin Q, Ward RL, Knowlton DR, Gabbay YB, Linhares AC, Rappaport R, Woods PA, Glass RI, Gentsch JR: Divergence of VP7 genes of GI rotaviruses isolated from infants vaccinated with reassortant rhesus rotaviruses. Arch Virol 1996, I 4I:2057-2076.

13. Kapikian AZ, Hoshino Y, Chanock RM: Rotaviruses. In Fields virology Edited by: Howley PM. Philadelphia, Lippincott Williams \& Wilkins; 200I:I787-I833.

14. Linhares AC, Lanata CF, Hausdorff WP, Gabbay WP, Black RE: Reappraisal of the Peruvian and Brazilian lower titer tetravalent rhesus-human reassortant rotavirus vaccine efficacy trials: analysis by severity of diarrhea. Pediatr Infect Dis J 1999, 18:1001-1016.

15. Liprandi F, Gerder M, Bastidas Z, Lopez JA, Pujol FH, Ludert JH, Joelsson DB, Ciarlet MA: Novel Type of VP4 Carried by a Porcine Rotavirus Strain. Virology 2003, 31 5:373-380.

16. Martella V, Ciarlet M, Camarda A, Pratelli A, Tempesta M, Greco G, Cavalli A, Elia G, Decaro N, Terio V, Bozzo G, Camero M, Buonavoglia C: Molecular characterization of the VP4, VP6, VP7, and NSP4 genes of lapine rotaviruses identified in Italy: emergence of a novel VP4 genotype. Virology 2003, 3 14:358-370.

17. Maunula $\mathrm{L}$, von Bonsdorff $\mathrm{C}-\mathrm{H}$ : Short sequences define genetic lineages: phylogenetic analysis of group $A$ rotaviruses based on partial sequences of genome segments 4 and 9. J Gen Virol 1998, 79:321-332.

18. Nicholas KB, Nicholas HB, Deerfield DW: GeneDoc: analysis and visualization of genetic variation. Embnet News 1997, 4:14.

19. Okada J, Urasawa T, Kobayashi N, Taniguchi K, Hasegawa A, Mise K, Urasawa S: New $\mathbf{P}$ serotype of group $\mathbf{A}$ human rotavirus closely related to that of a porcine rotavirus. J Med Virol 2000, 60:63-69.

20. Parashar UD, Hummelman EG, Bresee JS, Miller MA, Glass RI: Global illness and deaths caused by rotavirus disease in children. Emerg Infect Dis 2003, 9:565-572.

21. Rao CD, Gowda K, Reddy BS: Sequence analysis of VP4 and VP7 genes of nontypeable strains identifies a new pair of outer capsid proteins representing novel $\mathbf{P}$ and $\mathbf{G}$ genotypes in bovine rotaviruses. Virology 2000, 276: 104-II3.

22. Santos N, Hoshino $\mathrm{Y}$ : Global distribution of rotavirus serotypes/genotypes and its implication for the development and implementation of an effective rotavirus vaccine. Rev Med Virol 2005, 15:29-56

23. Sereno MM, Gorziglia MI: The outer capsid protein VP4 of murine rotavirus strain $E b$ represents a tentative new $P$ type. Virology 1994, 199:500-504.

24. Thompson JD, Gibson TJ, Plewniak F, Jeanmougin F, Higgins DG: The CLUSTAL_ $X$ windows interface: flexible strategies for multiple sequence alignment aided by quality analysis tools. Nucleic Acids Res 1997, 25:4876-4882.

25. Unicomb LE, Bingnan F, Rahim Z, Banu NN, Gomes JG, Podder G, Munshi MH, Tzipori SR: A one-year survey of rotavirus strains from three locations in Bangladesh. Arch Virol 1993, I32:20|-208.

26. Unicomb LE, Podder G, Gentsch JR, Woods PA, Hasan KZ, Faruque AS, Albert MJ, Glass RI: Evidence of high-frequency genomic reassortment of group $A$ rotavirus strains in Bangladesh: emergence of type G9 in 1995. J Clin Microbiol 1999, 37:1885-189I.

27. Unicomb LE, Kilgore PE, Faruque ASG, Hamadani JD, Fuchs G], Albert MJ, Glass RI: Anticipating rotavirus vaccines: hospital-based surveillance for rotavirus diarrhea and estimates of disease burden in Bangladesh. Pediatr Infect Dis J 1997, 16:947-95 I.

28. Ward RL, McNeal MM, Clemens JD, Sack DA, Rao M, Huda N, Green KY, Kapikian AZ, Coulson BS, Bishop RF: Reactivities of serotyping monoclonal antibodies with culture-adapted human rotaviruses. J Clin Microbiol I99I, 29:449-456.
Publish with BioMed Central and every scientist can read your work free of charge

"BioMed Central will be the most significant development for disseminating the results of biomedical research in our lifetime. "

Sir Paul Nurse, Cancer Research UK

Your research papers will be:

- available free of charge to the entire biomedical community

- peer reviewed and published immediately upon acceptance

- cited in PubMed and archived on PubMed Central

- yours - you keep the copyright
BioMedcentral 